\title{
Comparisons of Watershed Delineation of River Network Representation and Morphometric Analysis in Karnaphuli River Basin, Chittagong, Bangladesh: A study with Different Digital Elevation Model (DEM)
}

Sujit Kumar Roy ( $\nabla$ sujitroy.bejoy@gmail.com )

Bangladesh University of Engineering and Technology (BUET) https://orcid.org/0000-0003-4465-9053

Md. Arif Chowdhury

Jashore University of Science and Technology

Swapan Talukdar

University of Gour Banga

Md Mostaim Billah

Bangladesh University of Engineering and Technology

Anik Chandra Banik

Bangladesh University of Engineering and Technology

Javed Mallick

King Khalid University

Research Article

Keywords: Morphometric Analysis, Watershed, Drainage Network, Karnaphuli River, DEM, ASTER, SRTM

Posted Date: January 17th, 2022

DOI: https://doi.org/10.21203/rs.3.rs-1243899/v1

License: (c) (i) This work is licensed under a Creative Commons Attribution 4.0 International License. Read Full License 


\section{Abstract}

The present study aimed to delineate robust watershed boundary and extract its morphometric parameters in Karnaphuli watershed, Bangladesh using different types of digital elevation models (DEMs). Two DEMs, such as Shuttle Radar Topographic Mission (SRTM) and the Terra Advanced Spaceborne Thermal Emission and Reflection Radiometer (ASTER), were utilized to delineate watershed boundary and evaluate several morphometric characteristics. From the findings, it is revealed that there is a visual difference between the data sets as ASTER has a larger watershed area than SRTM. Also, regarding stream order, there are actually 1 to 6 orders of stream, so there are so many small, medium and main channels of the river, where the drainage density for SRTM (spatial resolution: $30 \mathrm{~m}$ ) and ASTER (spatial resolution: $30 \mathrm{~m}$ ) is $0.52 \mathrm{~km} / \mathrm{km}^{2}$ and $0.51 \mathrm{~km} / \mathrm{km}^{2}$. The bifurcation ratio ranges from 1.94 and 2.45 for SRTM and ASTER, respectively, representing the influence of geological structure as well as suffering more structural disturbances. The form factor denotes the study area's elongated shape. The entire dimension of the stream and the extent of the watershed imply that the mean annual rainfall discharge is moderate. The watershed has rather high denudation rates, according to the basin relief. The watershed's drainage density is low, demonstrating that infiltration is more important. This study may help policymakers to take decisions on the Karnaphuli River on conservation of the river stream and flow path, which will ultimately enrich the river ecology and other vegetation cover in Chittagong, Bangladesh.

\section{Introduction}

Geomorphometry is a quantitative land surface analysis science that could be applied to compute land surface characteristics (for example slope, aspect, topographic wetness index, and so on) and objects (such as a watershed line, cirque, alluvial fan, drainage network, and so on) (Beheshti Javid et al., 2018; Hengl \& Evans, 2009). Analysing basin morphometry and delineating watershed are important in river basin studies because it provides essential information about the drainage networks (Abdeta et al., 2020), topographic factors (Nikolova et al., 2021), geology (Ghosh et al., 2020), and climatic (Gebremeskel \& Kebede, 2018) features of the basin. As a consequence, numerous researchers across the world have been determining the morphometric properties of basins in respect of better understand the physical aspects of their research regions and obtain thorough information concerning them.

Several methodologies and techniques may be used in basin studies to extract borders, drainage networks, and morphometric characteristics. While some researchers choose conventional methods such as topographical maps and field surveys to support their investigations, others prefer modern methods such as GIS-produced DEMs and digital surface models (DSMs) and remote-sensing techniques (Bove et al., 2020; Rogers et al., 2020). DEMs could be acquired from a variety of sources, including topographic maps, DGPS field surveys, radar interferometry, satellite data, drones, and contour maps. Satellite-based DEMs have grown admiration resulting from their accessibility and ease of usage. More improved resolutions and open access to DEMs have become accessible in the last decade, such as the Advanced Spaceborne Thermal Emission and Refection Radiometer (ASTER) (version 2, $30 \mathrm{~m}$ ), SRTM with $90 \mathrm{~m}$ and 30 m, Advanced Land Observing Satellite (ALOS), Panchromatic Remote-sensing Instrument for Stereo Mapping-30 m (PRISM). As a result, DEM and DSM are sophisticated techniques that can accurately compute features. The use of remote sensing data in this regard is very effective as GIS and imageprocessing techniques can be functional for demarcation of morphological parameters of the basin and drainage patterns (Tribhuvan \& Sonar, 2016). DEMs have been frequently utilised in basin morphometric investigations. The spatial resolution of DEMs influences their capacity to reveal surface topography characteristics (López-Vicente \& Álvarez, 2018). High-resolution DEMs can give more comprehensive topographic information (H. Zhao et al., 2017).

A watershed is an area that acts as a catchment for water to convey the water to common outlets (Bajjali, 2018). It is a fundamental hydrologic unit used for hydrologic design and for studying the movement, distribution, quality, and quantity of water in a specific area (Bajjali, 2018). Watershed properties are important for determining and predicting hydrological systems as well as for designing watershed management strategies (Liu et al., 2016). Accurate delineation of watersheds is important for simulating runoff and drainage (Li et al., 2019). However, because of large depressions and subtle elevation differences on a local scale it is difficult to derive an accurate river network from conventional Digital Elevation Model (DEM) processing methods (Lai et al., 2016; Li et al., 2019). Satellite images in combination with different algorithms and analysis techniques are helpful in this regard to developing more accurate watersheds and river networks (Lai et al., 2016; Li et al., 2019).

Watershed parameters constitute the basic units for monitoring the health of the watershed as well as understanding natural resources and environmental issues (Hazbavi, 2018). Using a Geographic Information System (GIS) to analyze morphometric parameters such as stream ordering has been shown in studies to be a useful method for studying the hydrological behaviours of watersheds (Kumar et al., 2018). These parameters, such as basin area, bifurcation ratio, and sinuosity of a stream channel all have direct impact the storm hydrograph and the magnitude of peak and mean runoff (Chorley, 2019). The drainage characteristics show the effect of these drivers' variance from location to location. Detailed morphometric investigations shed light on basin succession and the function of drainage morphometry in the formation of landforms and their features. The slope, size, form, drainage density, and length of streams are all physiographic features of drainage basins that can be linked to several significant hydrologic phenomena and it's an important technique in any hydrological research, such as identification of groundwater potential zone, paedology, environmental evaluation, and it's a topic that both geomorphologists and hydrologists are interested in (Kumar et al., 2018; Sahu et al., 2018). The morphometric parameters are used to define and compare the basin traits and processes that illustrate the drainage basin's geologic and geomorphic evolution (Strahler, 1964). Understanding the dynamics of a watershed requires morphometric study. Basically, drainage basin morphometry aims to illustrate and forecast long-term basin dynamics that lead in morphological changes within the basin (Mahala, 2020), as well as to outline physical changes in the drainage system through time in consequence to natural or human interruptions (Kuntamalla et al., 2018).

Morphometric investigation has been widely used as an indirect technique for soil estimation, groundwater movement prediction, landslide susceptibility mapping, and topography analysis in earth science and engineering domains (Basu \& Pal, 2019). This work aims to examine the morphometric characteristics and delineate the watershed using the SRTM DEM, which can have better precision than the ASTER GDEM (Elkhrachy, 2018; Khasanov, 2020). Although, the present compares the accuracy of ASTER GDEM and SRTM DEM to compute and delineate watershed and its morphometric features. Both Ozdemir and Bird (2009) and Karabulut and Özdemir (2016) used a 1:25.000 scaled topographic map and a $10 \mathrm{~m}$ resolution DEM to create drainage networks. They used this

Page $2 / 20$ 
DEM as a baseline for analysing the performance of the ASTER GDEM (30 m) and SRTM DEM analyses (30 m). In addition to SRTM (90 m), ASTER GDEM (30 m), and CartoDEM, Das et al. (2016) employed DEMs generated from 1:50.000 and 1:250.000 topographic maps. DEMs generated from a 1:50.000 topographical map and ASTER GDEM V2 data have been considered to be more reliable and dependable in regards to absolute accuracy in their analysis. For the appropriate management and planning of watersheds, Ahmed et al. (2010) evaluated certain morphometric characteristics generated from topographic maps (1:50,000), ASTER DEM (30 m), and SRTM DEM (90 m). They came to the conclusion that both the ASTER and SRTM datasets produce satisfactory findings, and that the DEM cell size is also essential. Zhao et al. (2011) Topography maps were used to test the efficacy of ASTER DEM (30 m) and SRTM DEM $(90 \mathrm{~m})$ in expressing elevation data. In certain locations, both the ASTER and the SRTM produced comparable findings, while the ASTER failed in flat or slightly sloping terrain.

The low elevation terrain of coastal Bangladesh, combined with the abundance of rivers and the monsoon season, makes the region extremely vulnerable to natural disasters (Rahman \& Rahman, 2015). The south-eastern hilly region is highly susceptible to flash flooding following heavy rainfall events. As a result, a thorough study of the river basins in this region, which are dominated by the Karnaphuli and Sangu rivers, is essential (Adnan et al., 2019). The Chittagong seaport plays the biggest role in the economy of Bangladesh; hence, the importance of understanding the Karnaphuli River is undeniable (S. K. Roy \& Navera, 2018). However, waterlogging due to intense rainfall events is a longstanding problem in Chittagong city and the region covered by the Karnaphuli River basin (Mahmood \& Matin, 2018). Progressive changes in the landscape within the basin, and the reduction of drainage capacity for various reasons, along with the impacts of climate change, make the situation even worse (Masum et al., 2020). Number of studies have been carried out focusing on flash flood susceptibility, land use-land cover, morphological changes, water security, contamination, flow parameters, and economic development in the estuary of the Karnaphuli River (Adnan et al., 2019; Akter \& Tanim, 2021; Alam \& Hossain, 2020; Ali et al., 2016; Islam et al., 2017; S. K. Roy \& Navera, 2018; Sultana et al., 2020), which indicate the importance of this region (Akter \& Tanim, 2021). In a watershed, the catchment is the lowest spatial entity of the delineated region where collective management of water can be implemented (Akram et al., 2012). Also, DEMs are very applicable to various aspects, where this is one of the most primary conditions for diverse applications, where they are mostly useful in areas that are derived from detailed topographic outline (Kim \& Kang, 2001; Vadon, 2003).

The major goal of this research is to find out, "Which form of digital elevation model offers realistic results in terms of surface morphology and morphometry?" Even, no such studies have been undertaken in the study area and also very rare studies have been conducted in Bangladesh. Most of the studies have to rely on the watershed and drainage network as their basis. Therefore, it is important to improve the understanding and accuracy of the watershed and drainage patterns that underpin all of the studies. Continuous improvement in this regard is necessary, which is why this study has been carried out with the overall objective of enhancing the current understanding of the Karnaphuli River and its basin area. Specifically, this study was conducted to outline the catchment delineation and evaluate the drainage network of the Karnaphuli River in Chittagong, Bangladesh using DEM data and GIS techniques. By studying the morphometric analysis utilizing Remote Sensing and GIS, the current study elucidates the varied drainage characteristics of one of the watersheds of the Karnaphuli Water Basin in Chittagong. The research will help researchers better understand the hydrological behaviour of the watershed, including different climatic factors.

\section{Methodology}

\subsection{Study Area}

Karnaphuli River is one of the most significant rivers in Chittagong (Figure 1). The river originates from the Lushai Hills of Mizoram, India having a total catchment area of about $11,000 \mathrm{~km}^{2}$ (T. Ahmed et al., 2013). This rivers flows over $180 \mathrm{~km}$ of mountainous wilderness in Chittagong Hill Tract and then flows for approximately $170 \mathrm{~km}$ through the port city of Chittagong before draining into the Bay of Bengal $\left(22^{\circ} 12 \mathrm{~N}, 91^{\circ} 47 \mathrm{E}\right)$ (Ali et al., 2016$)$. From February to November, the highest and lowest temperatures are above $35^{\circ} \mathrm{C}$ and $24.5^{\circ} \mathrm{C}$, respectively (S. Roy et al., 2020). The flow of this river varies greatly due to the high variation in rainfall during the monsoon and dry seasons. The main watershed of the river is elongated in the north-south direction, which lies within narrow valleys between parallel ridges of hills, through which the river has cut its channel. The Karnafuli river basin's topography is fairly flat and low in the downstream portion, but quite rugged in the upstream portion (T. Ahmed et al., 2013). Geologically, the entire river catchment is formed with tertiary rocks with alluvial deposits (Wang et al., 2016).

\subsection{Materials}

The identification and delineation of watershed and drainage networks were downloaded from two different sources, such as SRTM DEM (https://earthexplorer.usgs.gov/) and ASTER DEM (https://earthdata.nasa.gov/). The SRTM DEM products mainly found in two forms; these are the SRTM 30 $\mathrm{m}$ and SRTM $90 \mathrm{~m}$ spatial resolutions respectively. But in these studies, only 30m SRTM and ASTER DEM $30 \mathrm{~m}$ have been used in these studies and the format of the images is tif (Tag image file).

\subsection{Work Procedure}

The study area's delineation and drainage basin analysis are done quantitatively using the Arc-hydro tool in ArcGIS 10.5 software. The methodology used to define the drainage network and watershed boundaries is depicted in Figure 2.

\subsubsection{Fill}

DEMs are typically composed of depressions in the form of sinks and tall cells that trap and obstruct the flow of water. In this case, the DEM filling function was used to sink the cell to be filled, and tall cells were first cut off (Batis \& Ahmed, 2014). In Figure 3, before filling and after filling are presented. 


\subsubsection{Flow direction}

According to the filled DEM, the flow direction was determined for each pixel. The numerical value from 1 to 128 in the flow direction cell is distributed in eight directions: east, west, south, north, southeast, southwest, northwest, and northeast (Figure 4). At all times, the water flows in the direction of the steepest neighboring cell value (Batis \& Ahmed, 2014).

\subsubsection{Flow accumulation}

Flow accumulation is the hydrological modeling process, which creates a drainage network based on the flow direction of each cell. A trial-and-error method was used to extract the drainage network by considering pixels larger than a threshold by 2000 (Mark, 1983). Different studies represents that the threshold value depends on the study area and many other specifications of the study areas (Arnold, 2010; Qin \& Zhan, 2012; Schäuble et al., 2008). In our study we define based on hilly areas specification and depending on our outcome.

\subsubsection{Watershed Delineation}

Basically, Drainage basins are delineated by the identification of ridge lines among basins and the input flow direction raster is analyzed to detect all the cells in the same drying basin that are connected. The drainage basin are established by locating the dumps in the edges of the analysis window (where water is poured out of the raster) and sinks. The dumping area over each dump is then identified. This leads to a drainage basin raster. 


\begin{tabular}{|c|c|c|c|}
\hline Sl.no & $\begin{array}{l}\text { Parameters } \\
\text { And Symbol }\end{array}$ & Formula & References \\
\hline \multicolumn{4}{|c|}{ Linear aspects } \\
\hline 1 & Basin length, $L_{b}$ & $L_{b}=1.3129 A^{0.568}$ & $\begin{array}{l}\text { (Sreedevi et al., } \\
\text { 2005) }\end{array}$ \\
\hline 2 & Basin perimeter, $\mathrm{P}$ & $\mathrm{P}=$ outer boundary of drainage basin measured in kilometers & $\begin{array}{l}\text { (Sreedevi et al., } \\
\text { 2005) }\end{array}$ \\
\hline 3 & Stream order, $\mathrm{U}$ & Hierarchical rank & (Strahler, 1964) \\
\hline 4 & Stream length, Lu & Length of the stream in each order & (R. Horton, 1945) \\
\hline 5 & $\begin{array}{l}\text { Mean stream length, } \\
\text { Lsm }\end{array}$ & $\begin{array}{l}L_{s m}=L_{u} / N_{u} \text {, where } L_{u}=\text { total stream length of order ' } u \text { ', } N_{u}=\text { total no. of stream segments of order } \\
\text { ' }\end{array}$ & (Strahler, 1964) \\
\hline 6 & Stream number, $\mathrm{N}_{\mathrm{u}}$ & No. of streams in each order & $\begin{array}{l}\text { (Sreedevi et al., } \\
\text { 2013) }\end{array}$ \\
\hline 7 & $\begin{array}{l}\text { Stream length ratio, } \\
\mathrm{R}_{1}\end{array}$ & $\begin{array}{l}\mathrm{R}_{1}=\mathrm{L}_{\mathrm{u}} / \mathrm{L}_{\mathrm{u}-1} \text {, where } \mathrm{L}_{\mathrm{u}}=\text { the total stream length of the order ' } \mathrm{u} \text { ' } \mathrm{L}_{\mathrm{u}-1}=\text { total stream length of its } \\
\text { next lower order }\end{array}$ & (R. Horton, 1945) \\
\hline 8 & Bifurcation ratio, $R_{b}$ & $\begin{array}{l}R_{b}=N_{u} / N_{u+1}, N_{u}=\text { total no. stream segments of order ' } u \text { ', } N_{u+1}=\text { number of segments of the next } \\
\text { higher order }\end{array}$ & (Schumm, 1956) \\
\hline 9 & $\begin{array}{l}\text { Mean bifurcation } \\
\text { ratio }(\mathrm{Rbm})\end{array}$ & Average of bifurcation ratios of all orders & (Strahler, 1964) \\
\hline \multicolumn{4}{|c|}{ Areal aspects } \\
\hline 10 & Drainage density, $D_{d}$ & $D_{d}=L_{u} / A$ where, $L_{u}=$ total stream length of all orders and $A=$ area of the basin $\left(\mathrm{km}^{2}\right)$ & $\begin{array}{l}\text { (R. E. Horton, } \\
\text { 1932) }\end{array}$ \\
\hline 11 & Drainage texture, Rt & $R_{t}=N_{u} / P$, where $N_{u}=$ total no. of streams of all orders, $P=$ perimeter $(\mathrm{km})$ & (Smith, 1950) \\
\hline 12 & Stream frequency, $\mathrm{F}_{\mathrm{s}}$ & $F_{s}=N_{u} / A$, where $N_{u}=$ total no. of streams of all orders, $A=$ area of the basin $\left(\mathrm{km}^{2}\right)$ & (R. Horton, 1945) \\
\hline 13 & Elongation ratio, $\mathrm{Re}$ & $R_{e}=2 / L_{b} *(A / p)^{0.5}$ where $A=$ area of the basin, $L_{b}=$ basin length $(k m)$ & (Schumm, 1956) \\
\hline 14 & Circulatory ratio, $\mathrm{R}_{\mathrm{c}}$ & $\begin{array}{l}R_{c}=4 * \pi * A / P^{2} \text {, where } \pi=3.14, A=\text { area of the basin, } P^{2}=\text { square of the } \\
\text { perimeter }(k m)\end{array}$ & (Strahler, 1964) \\
\hline 15 & Form factor, $\mathrm{R}_{\mathrm{f}}$ & $R_{f}=A / L_{b}^{2}$, where $A=$ area of the basin $\left(\mathrm{km}^{2}\right), L_{b}{ }^{2}=$ square of basin length & (R. Horton, 1945) \\
\hline 16 & Infiltration number, $\mathrm{l}_{\mathrm{f}}$ & $I_{f}=D_{d} * F_{s}$ where $D_{d}=$ drainage density and $F_{s}=$ drainage frequency & (Umrikar, 2017) \\
\hline \multicolumn{4}{|c|}{ Relief aspects } \\
\hline 17 & Basin relief, Bh & Vertical distance between the lowest and highest points of basin & (Schumm, 1956) \\
\hline 18 & Relief ratio, $\left(R_{h}\right)$ & $R_{h}=B_{h} / L_{b}$, where $L_{b}=$ basin length & (Schumm, 1956) \\
\hline 19 & $\begin{array}{l}\text { Ruggedness number, } \\
\left(R_{n}\right)\end{array}$ & $R_{n}=B_{h} * D_{d}$ where $B_{h}=$ basin relief, $D_{d}=$ drainage density & (Strahler, 1964) \\
\hline
\end{tabular}

\subsection{Morphometric parameters}

The SRTM \& ASTER created a unique data set of worldwide elevations which is open to modelling and environmental applications (Sreedevi et al., 2005). The Arc GIS 10.5 software has been used for automated extraction of watershed and drainage systems as well as to delineate the Karnaphuli Watershed boundary. Again, a correlation between the morphometric parameters was established using MS Excel and IBM SPSS 25.

\subsubsection{Linear parameters}

The stream length illustrates the chronological development of stream segments and tectonic disturbance. In nature, the greater the order usually represents the longer stream. This equation is identical to the perimeter calculation for the calculation of stream lengths. Stream length ratio (RI) in the next sequence represents the ratio between the stream lengths of a given order and the total stream. Throughout the basin's several stream orders, RI tends to remain stable. The bifurcation ratio is obtained when the number of stream segments of one order is divided by the number of stream segments of the next higher level. For watersheds where geologic formations affect the drainage pattern, bifurcation ratios typically range from 3.0 to 5.0 . In areas of steeply dipping rock layers, where small strike valleys are limited between hogback ridges, abnormally high bifurcation ratios may be expected. Lower Rb values imply fewer structural disturbances while the disturbances cannot altered the drainage pattern (Strahler 1964). 


\subsubsection{Areal parameters}

Drainage density (Dd) is a portion of the basin's wetness and is demarcated as the overall length of streams in a catchment per unit area. When an area's drainage density is high, it means there's a lot of run-off and a low infiltration rate, accordingly when it's low, it means there's a lot of run-off and a high infiltration rate (Julius et al., 2017; Markose et al., 2014). Drainage texture (T) is known as relative channel spacing in a fluvial separated landscape while product of Dd and Fs is T. Vegetation, rock, soil type, infiltration rate, relief, climate, rainfall pattern, and the phases of development of a basin are all aspects to consider regarding $\mathrm{T}$ (Smith, 1950). The ratio of the total number of streams $(\mathrm{Nu})$ in a basin and the basin area is known as stream frequency (Fs) (Nongkynrih \& Husain, 2011; Rao et al., 2010). Low drainage frequency indicates greater percolation and thus higher groundwater potential, while high drainage frequency means more surface run-off (Choudhari et al., 2018; Hajam et al., 2013). The total number of streams ( $\mathrm{Nu}$ ) in a basin is divided by the total basin area to calculate stream frequency $(A)$. Schumm (1956) established the elongation ratio $(\mathrm{Re})$ as the ratio of the diameter of a circle with the same area as the drainage basin, where the basin's length is larger. In terms of run-off discharge, a circular basin differs from an elongated basin (Vittala et al., 2004). Re values range from 0.6 to 1.0 across a wide range of climatic and geologic characteristics. Here, closer to 1.0 and 0.6-0.8 indicates very low relief and steep terrain slope, respectively (Vittala et al., 2004). There are three types of Re values: (a) circular (0.9-0.10), (b) oval (0.7-0.9), and (c) elongated (<0.7). The circularity ratio (Rc) compares the area of a basin to the area of a circle with the same diameter (Vittala et al., 2004; Waikar \& Nilawar, 2014). Rc values of 0.5 and above depict that the basin is more or less circular, high to moderate relief, and structurally controlled drainage system. A drainage basin's form factor (Ff) is the proportional area of the basin's to the square of its length (R. Horton, 1945). The basin with a high Ff has higher peak flows for a shorter time, whereas the extended sub watershed with a low Ff has lower peak flows for a longer time (Chopra et al., 2005).

\subsubsection{Relief parameters}

Basin relief $(R)$ is a crucial component in determining a basin's denudational features. The difference in height between the basin's maximum and minimum points is referred to as basin relief. The relief ratio $(\mathrm{Rh})$ is the ratio of the total relief $(\mathrm{R})$ of the basin to the lengthiest dimension parallel to the main drainage line (Lb). It depicts the impact of the intensity of degradation processes on the drainage basin's slopes on its steepness (Jasmin \& Mallikarjuna, 2013; Morenode las Heras et al., 2010). By multiplying basin relief by drainage density, the roughness number (Rn) is obtained. Erosion is more susceptible in basins with high Rn values (Kabite \& Gessesse, 2018; Sadhasivam et al., 2020).

\section{Results}

\subsection{Watershed Delineation}

One of the most common operations in hydrologic assessments is watershed delineation. Watersheds can be automatically calculated using GIS technology employing digital elevation models (DEMs), which provide a good picture of the topography. Accurate watershed delineation is not an easy task for hilly areas due to access to available resources like data, time and cost issues. In this study, SRTM (30m) and ASTER (30m) DEM data were used to define the watershed in the selected Karnaphuli River. Figure 4 represents the watershed delineation of the selected river and its catchment area. Where there is a visual difference between the data sets, as ASTER has a larger watershed area than SRTM.

\subsection{Morphometric Analysis:}

\subsubsection{Area}

The total watershed is calculated for SRTM is $3060 \mathrm{sq.} \mathrm{km}$ and ASTER is $5401 \mathrm{sq.km}$ (Table 2). So mathematically, ASTER represents a big catchment area for the selected river basin.

\subsubsection{Perimeter}

The perimeter is the total length of the drainage basin boundary. According to Table 2 the perimeter is $125.27 \mathrm{~km}$ and $173.98 \mathrm{for}$ SRTM and ASTER, respectively.

\subsubsection{Total Number of Stream of all Order and Stream Length}

The values of total number of streams of all order for each watershed are shown in Table 2. The heights stream is found for ASTER 1236 and lowest for 677 for SRTM.

\subsubsection{Stream Order}

In a watershed, the drainage system is assessed based on the total length of the stream and the number of tributaries. The order of the stream or body of water is a optimistic number used in geomorphology and hydrology to specify the branching level in the river system. Distinctions of topological arrangements exist for rivers or stretches of rivers on the basis of their distance from the source ("top down") or confluence, or from the mouth ("bottom up") of rivers and their hierarchical location in the system of the river (Weishar et al., 2000). When DEM grid sizes are used for delineation, they have a significant influence on topographic representation and the hierarchy of stream networks. (Macarof \& Statescu, 2017). Figure 5 gives the different watershed parameters for SRTM$30 \mathrm{~m}$ and ASTER $30 \mathrm{~m}$ DEMs. One of the watershed factors that impacts the drainage network and slope is terrain morphology. With DEM resolution, the findings demonstrate the difference in stream ordering and stream network. For both of the data sets, it is found that there are actually 1 to 6 orders of stream, so there are so many small, medium and main channels of river. Stream order is most commonly used in general hydrological mapping. Stream order systems are also necessary for the methodical charting of a river system, as they allow for explicit stream labelling and ordering. 


\subsubsection{Stream Density}

Drainage density is used to determine the degree of fluvial segmentation, which is influenced by a number of characteristics, including erosion resistance, surface roughness, run-off intensity index, infiltration capacity, vegetation cover, and meteorological conditions (Reddy et al., 2004). Here, Dd indicates the intimacy of the spacing of channels. When there is a lot of precipitation, such as thunder showers, a lot of it runs off, resulting in additional surface drainage lines. The degree of surface runoff and the drainage texture of a region are influenced by the quantity of vegetation and the rainwater absorption capacity of soils. Semi-arid locations have a finer texture than wet regions because to the identical lithology and geologic formations. According to (Reddy et al., 2004), Low Dd is associated with thick vegetation, low relief, and highly resistant or permeable subsurface material. Weak or impermeable underlying material, scant flora, and hilly topography all contribute to high Dd. When Dd is high, the drainage texture is fine but, when Dd is low, the drainage texture is coarse. Stream density for SRTM $30 \mathrm{~m}$ and ASTER 30m is presented in Figure 6 . The climatic and physical factors of the drainage basin influence drainage density. The runoff in a watershed is affected by underlying rock type and soil permeability (infiltration difficulties); Increased surface water runoff and, as a result, more frequent streams will come from impermeable land or exposed bedrock. If all other drainage basin factors are equal, rugged locations or those with high relief will have a greater drainage density than other drainage basins. The infiltration and permeability of a drainage basin, as well as the shape of the hydrograph, are measured by drainage density. The drainage basin's climatic and physical characteristics have an impact on drainage density (Tucker et al., 2001; Tucker \& Bras, 1998).

Figure 6: Stream Density of SRTM-30m DEM

A high bifurcation ratio is connected with high drainage densities (Nautiyal, 1994; Nirmala et al., 2020; Waikar \& Nilawar, 2014). According to the Table 2 the value of drainage density is 0.523 and 0.518 for SRTM and ASTER, accordingly. Where figure 6 is also established to get a mapping presentation of drainage density.

\subsubsection{Bifurcation ratio $(\mathrm{Rb})$ of watersheds}

The stream ordering of distinct watersheds is depicted in Table 2. The average value of the bifurcation ratio (Rb) can be determined by determining the average value of the bifurcation ratio $(\mathrm{Rb})$ for a given channel network. According to Table 2 the calculated values for the studied watersheds are 1.95 and 2.45 for SRTM and ATER, accordingly has a similarity with (D. Das, 2014). These values are most common in locations where geologic structure has little effect on drainage patterns. A sharp peak would result from a rotund basin with a low bifurcation ratio, whereas a low but prolonged peak flow would result from an elongate basin with a high bifurcation ratio. 
Table 2

Morphometric results of Karnaphuli River Basin

\begin{tabular}{|c|c|c|c|c|c|c|c|c|c|c|c|}
\hline $\begin{array}{l}\text { SI } \\
\text { No }\end{array}$ & Parameters & SRTM Result & & & & & & ASTER Result & & & \\
\hline 1 & Area (km2) & 3060 & & & & & & 5401 & & & \\
\hline 2 & $\begin{array}{l}\text { Basin } \\
\text { Length } \\
(\mathrm{Km})(\mathrm{Lb})\end{array}$ & 125.27 & & & & & & 173.98 & & & \\
\hline 3 & $\begin{array}{l}\text { Perimeter } \\
(\mathrm{Km})(\mathrm{P})\end{array}$ & 418 & & & & & & 551 & & & \\
\hline 4 & $\begin{array}{l}\text { Stream } \\
\text { Order }\end{array}$ & 6 & & & & & & 6 & & & \\
\hline \multirow[t]{2}{*}{5} & No. of & I & II & III & IV & V & VI & I & II & III & IV \\
\hline & & 339 & 172 & 67 & 56 & 29 & 14 & 619 & 299 & 148 & 107 \\
\hline 6 & $\begin{array}{l}\text { Total } \\
\text { Number of } \\
\text { Stream }\end{array}$ & 677 & & & & & & 1236 & & & \\
\hline 7 & $\begin{array}{l}\text { Stream } \\
\text { length for } \\
\text { each order } \\
(\mathrm{Km})(\mathrm{Lu})\end{array}$ & 794.954697 & 451.604664 & 144.0426 & 116.5014 & 66.96763 & 28.62338 & 1413.573915 & 739.733403 & 287.042161 & 199 \\
\hline 8 & $\begin{array}{l}\text { Total } \\
\text { Length of } \\
\text { Stream all } \\
\text { Order }\end{array}$ & 1602.694379 & & & & & & 2798.497998 & & & \\
\hline 9 & $\begin{array}{l}\text { Mean } \\
\text { Length of } \\
\text { Stream } \\
(\text { Lsm })\end{array}$ & 1.17423146 & 2.62560851 & 2.14989 & 2.080382 & 2.309229 & 2.044527 & 2.28364122 & 2.47402476 & 1.93947406 & $1.8 €$ \\
\hline 10 & $\begin{array}{l}\text { Stram } \\
\text { Length } \\
\text { Ratio (R1) }\end{array}$ & NA & 0.56808855 & 0.318957 & 0.808798 & 0.574823 & 0.427421 & NA & 0.5233072 & 0.38803461 & $0.6 \mathrm{C}$ \\
\hline \multirow[t]{2}{*}{11} & $\begin{array}{l}\text { Bifurcation } \\
\text { Ration (Rb) }\end{array}$ & $\mathrm{I} / \mathrm{II}$ & II/III & III/IV & IV/V & $\mathrm{V} / \mathrm{VI}$ & NA & $\mathrm{I} / \mathrm{II}$ & II/III & III/IV & IV/ \\
\hline & & 1.97093023 & 2.56716418 & 1.196429 & 1.931034 & 2.071429 & NA & 2.070234114 & 2.02027027 & 1.38317757 & 2.05 \\
\hline 12 & $\begin{array}{l}\text { Mean } \\
\text { Bifurcation } \\
\text { Ration } \\
\text { (Rbm) }\end{array}$ & 1.947397207 & & & & & & 2.451729398 & & & \\
\hline 14 & $\begin{array}{l}\text { Mx-rel - Mn- } \\
\text { rel (m) }\end{array}$ & 255 & & & & & & 255 & & & \\
\hline 15 & $\begin{array}{l}\text { Drainage } \\
\text { density (D) } \\
(\mathrm{km} / \mathrm{km} 2)\end{array}$ & 0.523756333 & & & & & & 0.518144417 & & & \\
\hline 16 & $\begin{array}{l}\text { Drainage } \\
\text { texture (Rt) }\end{array}$ & 1.619617225 & & & & & & 2.243194192 & & & \\
\hline 17 & $\begin{array}{l}\text { Stream } \\
\text { frequency } \\
\text { (Fs) }\end{array}$ & 0.22124183 & & & & & & 0.22884651 & & & \\
\hline 18 & $\begin{array}{l}\text { Elongation } \\
\text { ratio }(\mathrm{Re})\end{array}$ & 0.498281886 & & & & & & 0.476642006 & & & \\
\hline 19 & $\begin{array}{l}\text { Circularity } \\
\text { ratio (Rc) }\end{array}$ & 0.220079577 & & & & & & 0.223543736 & & & \\
\hline 20 & $\begin{array}{l}\text { Infiltration } \\
\text { number, If }\end{array}$ & 0.11587681 & & & & & & 0.118575542 & & & \\
\hline 21 & $\begin{array}{l}\text { Form factor } \\
\text { (Rf) }\end{array}$ & 0.194996704 & & & & & & 0.178433143 & & & \\
\hline 22 & $\begin{array}{l}\text { Total relief } \\
(\mathrm{Km})(\mathrm{hm})\end{array}$ & 0.255 & & & & & & 0.255 & & & \\
\hline
\end{tabular}




\begin{tabular}{|lllc|}
\hline $\begin{array}{l}\text { SI } \\
\text { No }\end{array}$ & Parameters & SRTM Result & ASTER Result \\
\hline 23 & $\begin{array}{l}\text { Relief ratio } \\
\text { (Rh) }\end{array}$ & 0.002035603 & 0.001465686 \\
\hline 24 & $\begin{array}{l}\text { Ruggedness } \\
\text { number } \\
(\text { Rn) }\end{array}$ & 0.133557865 & 0.132126826 \\
\hline
\end{tabular}

\subsubsection{Stream Frequency (Fs)}

For the four watersheds, the Fs values arise is 0.22 both for SRTM and ASTER dem (Table 2). According to (Pangali Sharma et al., 2021), the higher the stream frequency and drainage density in a basin, the faster the runoff, and thus floods is more likely.

\subsubsection{Drainage Texture}

Table 2 shows the T values for four different watersheds. The readings are fairly close to 1.61 and 2.24 for SRTM and ASTER. The texture is coarse for drainage texture values of 4.0 and below; intermediate for Rt values of 4.0 to 10.0 ; fine for Rt values of 10.0 and above; ultrafine for drainage texture values of 15.0 and above (bad land topography) (Manjare et al., 2019). So, our study area falls in coarse texture.

\subsubsection{Form Factor (Rf)}

The Rf values for the four watersheds range from (Table 2). A basin with a low form factor experiences less heavy rainfall concurrently over its full area than a basin with a large form factor. Forms factor varies from 0.20 and 0.18 for SRTM and ASTER DEM in the study area.

\subsubsection{Ratio of Circularity (Rc)}

The greater Rc, the more circular the sub-watersheds are, with high to medium relief and a structurally regulated drainage system, whereas the lower the Rc value, the more elongated the shape. The Rc for watersheds is 0.220 and 0.223 for SRTM and ASTER dem. The sub-watersheds are nearly extended, with little runoff flow and high permeability of subsurface material.

\subsubsection{Ratio of Elongation (Re)}

Re varies between 0.50 and 0.48 for the four watersheds (Table 2). The elongation ratio, according to Strahler (1964), varies from 0.6 to 1.0 across a wide range of climate and geology types. Closer to 1.0 indicates very little relief, whereas 0.6 to 0.8 indicates noteworthy relief and a steep ground slope. The Re value of Karnaphuli river basin watershed is 0.47 (Table 2) the watershed has limited infiltration capacity and considerable soil erosion due to heavy runoff, indicating relatively high relief, steep slope, and elongated. (Rawat et al., 2021) is vulnerable to floods.

\subsubsection{Infiltration number (If)}

The infiltration number (If) is a crucial factor in determining the basin's infiltration characteristics, and it is proportional to the basin's infiltration capacity. According to the analysis, the Karnaphuli watershed's infiltration number is 0.11 (Table 2 ) signifying that the infiltration capacity is relatively poor, resulting in very momentous runoff, which causes downstream flooding.

\subsubsection{Basin Relief $(H)$ and Relief Ratio (Rh)}

Understanding the geomorphic process and landform characteristics requires a thorough understanding of basin relief. The basin relief was calculated using the vertical separation between the basin's lowest and highest points. Relief has an inextricable relationship with other basin characteristics, and it has a stronger impact on some indices of basin response, such as highest run-off rates as well as sediment delivery, than on others. Basin relief is a measurement of a drainage basin's potential energy, and the higher the relief, the stronger the erosional forces operating on it. In this study, lower relief ( $0 \mathrm{~m})$ and greater relief $(255 \mathrm{~m})$ suggest negligible erosion. Figure 7 representing the Relative Relief in the study area. The relief ratio is the ratio of maximum relief to horizontal distance along the basin's longest dimension parallel to the main drainage line. In general, the relief ratio rises as the drainage area and size of the watershed in a given basin decrease. There is a robust link between the drainage basin's relief ratio and hydrological parameters (Singh et al., 2018). The highest relief ratio indicates a steep slope with high relief, whereas the lowest relief ratio indicates a low slope with low relief. The study region has a relief ratio of 0.002 and 0.001 . The relief ration value is relatively low, implying that sediment loss per unit area will be very minimal.

\subsubsection{Ruggedness Number}

According to (Strahler, 1968), roughness number is the product of the basin's relief and drainage density, when both parameters are in the similar unit. When both factors are large and the slope is steep, the roughness number reaches an abnormally high value (Arulbalaji \& Padmalal, 2020). The toughness value in this research is 1.96 . It means that peak discharges are anticipated to be higher than usual.

\section{Discussion}

Overall, several DEMs were compared in respect to watershed delineation and morphometric analysis in this work. The current study is unique in that it is the first use of its kind in the study region, and it could be used to manage water resources.

The morphometric research found that, in terms of a number of criteria, for the most part, the values from the various DEMs did not differ significantly and get within a comparable range. However, the precision of the watershed delineation, on the other hand, is heavily dependent on the correctness and good quality 
of the supplied Digital Elevation Model (DEM). Field observations and topographic maps are examples of traditional approaches, as well as sophisticated approaches such as remote sensing and DEMs, is used to delineate drainage networks. Using Remote Sensing and GIS, a systematic investigation of morphometric parameters within the drainage network can give great value in understanding basin features (S. A. Ahmed et al., 2010) (S. A. Ahmed et al., 2010). The watershed's drainage morphometric analysis offers information on the history of land surface processes and their formation, as well as the watershed's hydrologic behavior (Aouragh \& Essahlaoui, 2018; Arabameri et al., 2018; Rahmati et al., 2019).

In this study, SRTM-30m and ASTER-30m DEM data is used for defining watershed is Karnaphuli River. Where the watershed delineation found from those data has a different boundary area, but the result of the drainage density found has a similarity for the case of both data. However, it can be stated from the results that the SRTM has produced good results as the study area is in hilly region. It was discovered that there is no substantial impact of geological features on drainage development in the study's watershed. The region is well fed by streams of up to 6 orders, indicating that the watershed generates modest runoff. Similarly, the stream length findings indicate that there is unlikely to be an uplifting in the basin since the watershed area is solely dependent on drainage features for water movement. As a result of the prolonged water circulation, the watershed is extremely active hydrologically (Luo \& Harlin, 2003). The watershed has homogeneous foundation lithology and is geologically stable, based on the geometric connection between stream order and stream number. Similarly, stream length estimates indicate that there is unlikely to be any uplift in the basin since the watershed area is solely dependent on drainage features for water movement. The study concludes that the studied region is permeable and appropriate for groundwater recharge and water gathering buildings based on the various morphological factors evaluated. This information could aid in flood management and watershed management. Yadav and Indu (2016) employed a variety of DEMs as reference datasets in their investigation, including SRTM (30 m), ASTER (30 m), Cartosat-1 (30 m), and 1:250,000 topographic maps that are scaled. Over the basin, the SRTM DEM exhibited greater accuracy than other data sources. Thomas and Prasannakumar (2015) employed SRTM DEM (90 m), ASTER DEM (30 m), and 1:50,000 scaled topography maps to derive drainage networks and devise morphometric parameters for their research region. They discovered that drainage networks built from ASTER and SRTM DEMs produced findings that were consistent with topographical maps. When contrasted to ASTER, however, SRTM $(90 \mathrm{~m})$ produced superior findings (30 m). Different study was conducted internationally using the SRTM and ASTER DEM data but in most of the case their output goes for the SRTM DEM data in respect of accuracy (Forkuor \& Maathuis, 2012; Nikolakopoulos et al., 2006; Pryde et al., 2007).

This work will be extremely beneficial to our country, as there has been no substantial research on the Karnaphuli River utilising DEM data. Policymakers will have an easier time making decisions about this river, and river-related government and non-government organisations will be much more technical in conserving this river's stream and flow channel in order to enhance the river ecology and vegetation cover.

\section{Conclusion}

Many techniques linked to water resources management and flood mitigation rely on morphometric analysis. With the progress of technology, digital elevation models have become more widely utilised in geomorphological research, and have largely supplanted conventional topographic map-based approaches. This is due to the simplicity with which the parameters may be obtained, used, and extracted. However, given the variety of DEM sources available, it is necessary to select the best one for the study. With this goal in mind, the current study attempted to compare the several frequently used DEMs and determine which one is optimal for morphometric parameters for a plain area computation. The results of this study illustration that remote sensing and geographic information systems techniques are more effective for morphometric parameter computation and analysis. The morphometric investigation of the Karnaphuli River watershed has revealed that the basin has a mixture of landforms comprising of high hilly regions and low-lying plains. The watershed's elongated shape was shown by the form factor, circulation ratio, and elongation ratio data. The watershed's bifurcation ratio and stream numbers indicate that it is vulnerable to unanticipated flooding following heavy rains. The value of the mean bifurcation ratio specifies that structural disturbances and geological features have no effect on the watershed. The watershed is created by a permeable subsurface, and runoff is moderate, as evidenced by the low drainage density, stream frequency, and infiltration numbers. The low drainage density indicates an appropriate size for building water collecting facilities in streams. Because of the high basin relief, relief ratio, and roughness number, peak discharge is expected to be larger, and sediment yield per unit area is low. In flood control, soil erosion evaluation, and water resource management, morphometric characteristics of watershed delineation such as drainage density, stream frequency, and bifurcation ratio are critical for integrated decision making.

Karnaphuli watershed morphometric analysis provides useful facts and results for planning watershed development initiatives in the area. With the Chittagong district on the verge of becoming a lowland area, this investigation and its findings will be critical in watershed management and development in the studied area. Further study can be conducted with the participation of local people participation and application of ground level data on the Karnaphuli River in Chittagong, Bangladesh.

\section{Declarations}

\section{Acknowledgement}

Authors are thankful to Sonia Binte Murshed and Shampa, Assistant Professor, IWFM, BUET for their guidance during this study.

Funding: This research got no specific funding from any public, commercial, or non-profit funding agency.

Disclosure statement: The authors report there are no competing interests to declare.

Availability of data and material: Raw data was collected from USGS website (https://earthexplorer.usgs.gov/) and the corresponding author will provide the datasets created and analyzed during this work with reasonable request.

\section{References}


1. Abdeta GC, Tesemma AB, Tura AL, Atlabachew GH (2020) Morphometric analysis for prioritizing sub-watersheds and management planning and practices in Gidabo Basin, Southern Rift Valley of Ethiopia. Applied Water Science 10(7):1-15

2. Adnan MSG, Dewan A, Zannat KE, Abdullah AYM (2019) The use of watershed geomorphic data in flash flood susceptibility zoning: a case study of the Karnaphuli and Sangu river basins of Bangladesh. Nat Hazards 99(1):425-448

3. Ahmed SA, Chandrashekarappa KN, Raj SK, Nischitha V, Kavitha G (2010) Evaluation of morphometric parameters derived from ASTER and SRTM DEMa study on Bandihole sub-watershed basin in Karnataka. J Indian Soc Remote Sens 38(2):227-238

4. Ahmed T, Alam S, Hasan MS (2013) Modeling climate change impact on hydrology of Karnafuli River basin using soil water assessment tool (SWAT). 4th International Conference on Water and Flood Management (ICWFM-2013), Dhaka, 529-536

5. Akram F, Rasul MG, Khan MMK, Amir M (2012) Automatic Delineation of Drainage Networks and Catchments using DEM data and GIS Capabilities: A case study. Proceedings of the 18 Th Australasian Fluid Mechanics Conference, Launceston, Australia, 3-7

6. Akter A, Tanim AH (2021) Predicting Low Flow Thresholds of Halda-Karnafuli Confluence in Bangladesh. Water Security in Asia. Springer, pp 303-314

7. Alam SMR, Hossain MS (2020) A Rule-Based Classification Method for Mapping Saltmarsh Land-Cover in South-Eastern Bangladesh from Landsat-8 OLI.Canadian Journal of Remote Sensing,1-25

8. Ali MM, Ali ML, Islam MS, Rahman MZ (2016) Preliminary assessment of heavy metals in water and sediment of Karnaphuli River, Bangladesh. Environmental Nanotechnology, Monitoring \& Management 5:27-35

9. Aouragh MH, Essahlaoui A (2018) A TOPSIS approach-based morphometric analysis for sub-watersheds prioritization of high Oum Er-Rbia basin, Morocco. Spatial Information Research 26(2):187-202. https://doi.org/10.1007/s41324-018-0169-z

10. Arabameri A, Pradhan B, Pourghasemi HR, Rezaei K (2018) Identification of erosion-prone areas using different multi-criteria decision-making techniques and GIS. Geomatics, Natural Hazards and Risk 9(1):1129-1155. https://doi.org/10.1080/19475705.2018.1513084

11. Arnold N (2010) A new approach for dealing with depressions in digital elevation models when calculating flow accumulation values. Prog Phys Geogr 34(6):781-809

12. Arulbalaji P, Padmalal D (2020) Sub-watershed prioritization based on drainage morphometric analysis: a case study of Cauvery River Basin in South India. J Geol Soc India 95(1):25-35

13. Bajjali W (2018) Watershed delineation. ArcGIS for environmental and water issues. Springer, pp 235-245

14. Basu T, Pal S (2019) RS-GIS based morphometrical and geological multi-criteria approach to the landslide susceptibility mapping in Gish River Basin, West Bengal, India. Adv Space Res 63(3):1253-1269

15. Batis Kl, Ahmed SA (2014) Evaluation of morphometric parameters-a comparative study from Cartosat DEM, SRTM and SOI Toposheet in Karabayyanahalli sub-watershed, Karnataka. International Journal of Research 11:679-688

16. Beheshti Javid E, Esfandiyari Darabad F, Rostei S (2018) Evaluation of the Morphometric Effect of Landforms on Hydrological Processes of the Basin (Case Study: Northern Slopes of Sabalan). Hydrogeomorphology 4(16):177-197

17. Bove G, Becker A, Sweeney B, Vousdoukas M, Kulp S (2020) A method for regional estimation of climate change exposure of coastal infrastructure: Case of USVI and the influence of digital elevation models on assessments. Sci Total Environ 710:136162

18. Chopra R, Dhiman RD, Sharma PK (2005) Morphometric analysis of sub-watersheds in Gurdaspur district, Punjab using remote sensing and GIS techniques. J Indian Soc Remote Sens 33(4):531-539

19. Chorley RJ (2019) The drainage basin as the fundamental geomorphic unit. Introduction to physical hydrology. Routledge, pp 37-59

20. Choudhari PP, Nigam GK, Singh SK, Thakur S (2018) Morphometric based prioritization of watershed for groundwater potential of Mula river basin, Maharashtra, India. Geology, Ecology, and Landscapes 2(4):256-267

21. Das D (2014) Identification of erosion prone areas by morphometric analysis using GIS. Journal of the Institution of Engineers (India): Series A 95(1):6174

22. Das S, Patel PP, Sengupta S (2016) Evaluation of different digital elevation models for analyzing drainage morphometric parameters in a mountainous terrain: a case study of the Supin-Upper Tons Basin. Indian Himalayas SpringerPlus 5(1):1-38

23. Elkhrachy I (2018) Vertical accuracy assessment for SRTM and ASTER Digital Elevation Models: A case study of Najran city, Saudi Arabia. Ain Shams Engineering Journal 9(4):1807-1817

24. Forkuor G, Maathuis B (2012) Comparison of SRTM and ASTER derived digital elevation models over two regions in Ghana-Implications for hydrological and environmental modeling. INTECH Open Access Publisher London

25. Gebremeskel G, Kebede A (2018) Estimating the effect of climate change on water resources: Integrated use of climate and hydrological models in the Werii watershed of the Tekeze river basin, Northern Ethiopia. Agriculture and Natural Resources 52(2):195-207

26. Ghosh D, Mandal M, Karmakar M, Banerjee M, Mandal D (2020) Application of geospatial technology for delineating groundwater potential zones in the Gandheswari watershed, West Bengal. Sustainable Water Resources Management 6(1):1-14

27. Hajam RA, Hamid A, Bhat S (2013) Application of morphometric analysis for geo-hydrological studies using geo-spatial technology-a case study of Vishav Drainage Basin. Hydrology Current Research 4(3):1-12

28. Hazbavi Z (2018) Importance of geology and geomorphology in watershed health assessment. Poljoprivreda i Sumarstvo 64(4):277

29. Hengl T, Evans IS (2009) Mathematical and digital models of the land surface. Dev Soil Sci 33:31-63

30. Horton R (1945) Erosional development of stream and their drainage density: hydrophysical approach to quantitative geomorphology. Geol Soc Am Bull 56:275-370

Page $11 / 20$ 
31. Horton RE (1932) Drainage-basin characteristics. Eos, Transactions American Geophysical Union 13(1):350-361

32. Islam MR, Das NG, Barua P, Hossain MB, Venkatramanan S, Chung SY (2017) Environmental assessment of water and soil contamination in Rajakhali Canal of Karnaphuli River (Bangladesh) impacted by anthropogenic influences: a preliminary case study. Applied Water Science 7(2):997-1010

33. Jasmin I, Mallikarjuna P (2013) Morphometric analysis of Araniar river basin using remote sensing and geographical information system in the assessment of groundwater potential. Arab J Geosci 6(10):3683-3692

34. Julius JJ, Singh D, Brema J (2017) Morphometric analysis of linear and areal aspects of bhagirathi river basin-A GIS approach. 2017 2nd International Conference on Communication and Electronics Systems (ICCES), 549-554

35. Kabite G, Gessesse B (2018) Hydro-geomorphological characterization of Dhidhessa River basin, Ethiopia. International Soil and Water Conservation Research 6(2):175-183

36. Karabulut MS, Özdemir H (2016) Comparison of basin morphometry derived from ASTER and SRTM DEMs-a study on Çağlayan and Kabisre river basins (Northern Turkey). Recent Researches in Interdisciplinary Sciences. St. Kliment Ohridski University Press, Sofia, 445-456

37. Khasanov K (2020) Evaluation of ASTER DEM and SRTM DEM data for determining the area and volume of the water reservoir. IOP Conference Series: Materials Science and Engineering, 883(1), 12063

38. Kim S-B, Kang S-K (2001) Automatic generation of a SPOT DEM: Towards coastal disaster monitoring. Korean Journal of Remote Sensing 17(2):121-129

39. Kumar B, Venkatesh M, Triphati A (2018) A GIS-based approach in drainage morphometric analysis of Rihand River Basin, Central India. Sustainable Water Resources Management 4(1):45-54

40. Kuntamalla S, Nalla M, Saxena PR (2018) Morphometric Analysis of Drainage Basin through GIS: A Case Study from South Western part of Rangareddy District, Telangana State, India. International Journal of Advance Research in Science and Engineering, Volume 7:13-25

41. Lai Z, Li S, Lv G, Pan Z, Fei G (2016) Watershed delineation using hydrographic features and a DEM in plain river network region. Hydrol Process 30(2):276-288

42. Li L, Yang J, Wu J (2019) A method of watershed delineation for flat terrain using sentinel-2a imagery and DEM: A case study of the Taihu basin. ISPRS International Journal of Geo-Information 8(12):528

43. Liu W, Wei X, Li Q, Fan H, Duan H, Wu J, Giles-Hansen K, Zhang H (2016) Hydrological recovery in two large forested watersheds of southeastern China: the importance of watershed properties in determining hydrological responses to reforestation. Hydrol Earth Syst Sci 20(12):4747-4756

44. López-Vicente M, Álvarez S (2018) Influence of DEM resolution on modelling hydrological connectivity in a complex agricultural catchment with woody crops. Earth Surf Proc Land 43(7):1403-1415

45. Luo W, Harlin JM (2003) A THEORETICAL TRAVEL TIME BASED ON WATERSHED HYPSOMETRY. J Am Water Resour Assoc 39(4):785-792. https://doi.org/10.1111/j.1752-1688.2003.tb04405.x

46. Macarof P, Statescu F (2017) Comparasion of NDBI and NDVI as indicators of surface urban heat island effect in landsat 8 imagery: a case study of lasi. Present Environment and Sustainable Development 11(2):141-150

47. Mahala A (2020) The significance of morphometric analysis to understand the hydrological and morphological characteristics in two different morphoclimatic settings. Applied Water Science 10(1):1-16

48. Mahmood F, Matin MA (2018) ASSESSMENT OF DRAINAGE CAPACITY OF CHAKTAI AND RAJAKHALI KHAL IN CHITTAGONG CITY AND INUNDATION ADJACENT OF URBAN AREAS

49. Manjare B, Paunikar S, Shrivatra J (2019) Prioritization of sub-watersheds of Chandrabhaga river from Purna river basin, Maharashtra using geospatial techniques. Journ of Geosciences Research 2:111-120

50. Mark DM (1983) Relations between field-surveyed channel networks and map-based geomorphometric measures, Inez, Kentucky. Ann Assoc Am Geogr 73(3):358-372

51. Markose VJ, Dinesh AC, Jayappa KS (2014) Quantitative analysis of morphometric parameters of Kali River basin, southern India, using bearing azimuth and drainage (bAd) calculator and GIS. Environ Earth Sci 72(8):2887-2903

52. Masum MH, Hossen J, Pal SK (2020) PERFORMANCE EVALUATION OF DRAINAGE NETWORK USING HEC-HMS UNDER DIFFERENT CLIMATIC AND LAND USE CONDITIONS, A CASE STUDY

53. Moreno-de las Heras M, Nicolau JM, Merino-Martín L, Wilcox BP (2010) Plot-scale effects on runoff and erosion along a slope degradation gradient. Water Resources Research, 46(4)

54. Nautiyal MD (1994) Morphometric analysis of a drainage basin using aerial photographs: a case study of Khairkuli Basin, District Dehradun, UP. J Indian Soc Remote Sens 22(4):251-261

55. Nikolakopoulos KG, Kamaratakis EK, Chrysoulakis N (2006) SRTM vs ASTER elevation products. Comparison for two regions in Crete, Greece. Int J Remote Sens 27(21):4819-4838. https://doi.org/10.1080/01431160600835853

56. Nikolova V, Kamburov A, Rizova R (2021) Morphometric analysis of debris flows basins in the Eastern Rhodopes (Bulgaria) using geospatial technologies. Nat Hazards 105(1):159-175

57. Nirmala R, Singh RP, Verma N, Bongale P (2020) A GIS-Based Approach in Drainage and Morphometric Analysis of Suvarnavathi River Basin and Subwatersheds, Karnataka, India. Asian J Water Environ Pollut 17(4):81-87

58. Nongkynrih JM, Husain Z (2011) Morphometric analysis of the Manas river basin using earth observation data and geographical information system. International Journal of Geomatics and Geosciences 2(2):647-654 
59. Ozdemir H, Bird D (2009) Evaluation of morphometric parameters of drainage networks derived from topographic maps and DEM in point of floods. Environ Geol 56(7):1405-1415

60. Pangali Sharma TP, Zhang J, Khanal NR, Prodhan FA, Nanzad L, Zhang D, Nepal P (2021) A Geomorphic Approach for Identifying Flash Flood Potential Areas in the East Rapti River Basin of Nepal. ISPRS International Journal of Geo-Information 10(4):247

61. Pryde JK, Osorio J, Wolfe ML, Heatwole CD, Benham BL, Cardenas A (2007) Comparison of watershed boundaries derived from SRTM and ASTER digital elevation datasets and from a digitized topographic map

62. Qin C-Z, Zhan L (2012) Parallelizing flow-accumulation calculations on graphics processing units-From iterative DEM preprocessing algorithm to recursive multiple-flow-direction algorithm. Comput Geosci 43:7-16

63. Rahman S, Rahman MA (2015) Climate extremes and challenges to infrastructure development in coastal cities in Bangladesh. Weather and Climate Extremes 7:96-108. https://doi.org/10.1016/j.wace.2014.07.004

64. Rahmati O, Samadi M, Shahabi H, Azareh A, Rafiei-Sardooi E, Alilou H, Melesse AM, Pradhan B, Chapi K, Shirzadi A (2019) SWPT: An automated GISbased tool for prioritization of sub-watersheds based on morphometric and topo-hydrological factors. Geosci Front 10(6):2167-2175. https://doi.org/10.1016/j.gsf.2019.03.009

65. Rao NK, Latha SP, Kumar AP, Krishna HM (2010) Morphometric analysis of Gostani river basin in Andhra Pradesh State, India using spatial information technology. International Journal of Geomatics and Geosciences 1(2):179

66. Rawat A, Bisht MPS, Sundriyal YP, Banerjee S, Singh V (2021) Assessment of soil erosion, flood risk and groundwater potential of Dhanari watershed using remote sensing and geographic information system, district Uttarkashi, Uttarakhand, India. Applied Water Science 11(7):1-13

67. Reddy GPO, Maji AK, Gajbhiye KS (2004) Drainage morphometry and its influence on landform characteristics in a basaltic terrain, Central India-a remote sensing and GIS approach. Int J Appl Earth Obs Geoinf 6(1):1-16

68. Rogers SR, Manning I, Livingstone W (2020) Comparing the spatial accuracy of Digital Surface Models from four unoccupied aerial systems: Photogrammetry versus LiDAR. Remote Sensing 12(17):2806

69. Roy S, Akhtaruzzaman M, Nath B (2020) Spatio-seasonal variations of salinity and associated chemical properties in the middle section of Karnaphuli river water, Chittagong, Bangladesh using laboratory analysis and GIS technique. Int J Environ Sci Dev 11(8):372-382

70. Roy SK, Navera UK (2018) MORPHOLOGICAL RESPONSES OF A TIDAL RIVER DUE TO CLIMATE CHANGE: A CASE STUDY FOR KARNAFULI RIVER, BANGLADESH

71. Sadhasivam N, Bhardwaj A, Pourghasemi HR, Kamaraj NP (2020) Morphometric attributes-based soil erosion susceptibility mapping in Dnyanganga watershed of India using individual and ensemble models. Environ Earth Sci 79(14):1-28

72. Sahu U, Panaskar D, Wagh V, Mukate S (2018) An extraction, analysis, and prioritization of Asna river sub-basins, based on geomorphometric parameters using geospatial tools. Arab J Geosci 11(17):1-15

73. Schäuble H, Marinoni O, Hinderer M (2008) A GIS-based method to calculate flow accumulation by considering dams and their specific operation time. Comput Geosci 34(6):635-646

74. Schumm SA (1956) Evolution of drainage systems and slopes in badlands at Perth Amboy, New Jersey. Geol Soc Am Bull 67(5):597-646

75. Singh S, Kumar S, Mittal P, Kanhaiya S, Prakash P, Kumar R (2018) Drainage basin parameters of Bagh River, a sub-basin of Narmada River, Central India: Analysis and implications. Journal of Applied Geochemistry 20(1):91-102

76. Smith KG (1950) Standards for grading texture of erosional topography. Am J Sci 248(9):655-668

77. Sreedevi PD, Sreekanth PD, Khan HH, Ahmed S (2013) Drainage morphometry and its influence on hydrology in an semi arid region: using SRTM data and GIS. Environ Earth Sci 70(2):839-848

78. Sreedevi PD, Subrahmanyam K, Ahmed S (2005) The significance of morphometric analysis for obtaining groundwater potential zones in a structurally controlled terrain. Environ Geol 47(3):412-420

79. Strahler AN (1964) Part II. Quantitative geomorphology of drainage basins and channel networks. Handbook of Applied Hydrology: McGraw-Hill, New York, 4-39

80. Strahler AN (1968) Quantitative geomorphology. The Encyclopedia of Geomorphology,898-912

81. Sultana S, Islam MM, Alam MM (2020) An approach to open a new arena for blue growth of Bangladesh by mud crab (Scylla serrata) fishery from the Karnafuli River estuary, Chattogram; Bangladesh. Int J Fish Aquat Stud 8(2):249-257

82. Thomas J, Prasannakumar V (2015) Comparison of basin morphometry derived from topographic maps, ASTER and SRTM DEMs: an example from Kerala, India. Geocarto International 30(3):346-364

83. Tribhuvan PR, Sonar MA (2016) Morphometric analysis of a Phulambri river drainage basin (Gp8 Watershed), Aurangabad district (Maharashtra) using geographical information system. International Journal of Advanced Remote Sensing and GIS 5(6):1813-1828

84. Tucker GE, Bras RL (1998) Hillslope processes, drainage density, and landscape morphology. Water Resour Res 34(10):2751-2764

85. Tucker GE, Catani F, Rinaldo A, Bras RL (2001) Statistical analysis of drainage density from digital terrain data. Geomorphology 36(3-4):187-202

86. Umrikar BN (2017) Morphometric analysis of Andhale watershed, Taluka Mulshi, District Pune, India. Applied Water Science 7(5):2231-2243

87. Vadon H (2003) 3D Navigation over merged Panchromatic-Multispectral high resolution SPOT5 images. The International Archives of the Photogrammetry, Remote Sensing and Spatial Information Sciences 36(5):W10

88. Vittala SS, Govindaiah S, Gowda HH (2004) Morphometric analysis of sub-watersheds in the Pavagada area of Tumkur district, South India using remote sensing and GIS techniques. J Indian Soc Remote Sens 32(4):351-362

Page $13 / 20$ 
89. Waikar ML, Nilawar AP (2014) Morphometric analysis of a drainage basin using geographical information system: a case study. Int $J$ Multidiscip Curr Res, 2(2014), 179-184

90. Wang A, Kawser A, Xu Y, Ye X, Rani S, Chen K (2016) Heavy metal accumulation during the last 30 years in the Karnaphuli River estuary, Chittagong, Bangladesh. SpringerPlus 5(1):1-14

91. Weishar LL, Teal J, Hinkle R (2000) Development of marsh hydrogeomorphology and marsh vegetation within a salt hay farm wetland restoration site. Proceedings of the 27 Th Annual Conference on Ecosystems and Creation, Tampa, FL, 26-44

92. Yadav S, Indu J (2016) Estimation of vertical accuracy of Digital Elevation Models over complex terrains of Indian subcontinent. 2016 IEEE International Geoscience and Remote Sensing Symposium (IGARSS), 6036-6039. https://doi.org/10.1109/IGARSS.2016.7730577

93. Zhao H, Fang X, Ding H, Josef S, Xiong L, Na J, Tang G (2017) Extraction of terraces on the Loess Plateau from high-resolution DEMs and imagery utilizing object-based image analysis. ISPRS International Journal of Geo-Information 6(6):157

94. Zhao S, Cheng W, Zhou C, Chen X, Zhang S, Zhou Z, Liu H, Chai H (2011) Accuracy assessment of the ASTER GDEM and SRTM3 DEM: an example in the Loess Plateau and North China Plain of China. Int J Remote Sens 32(23):8081-8093

\section{Figures}

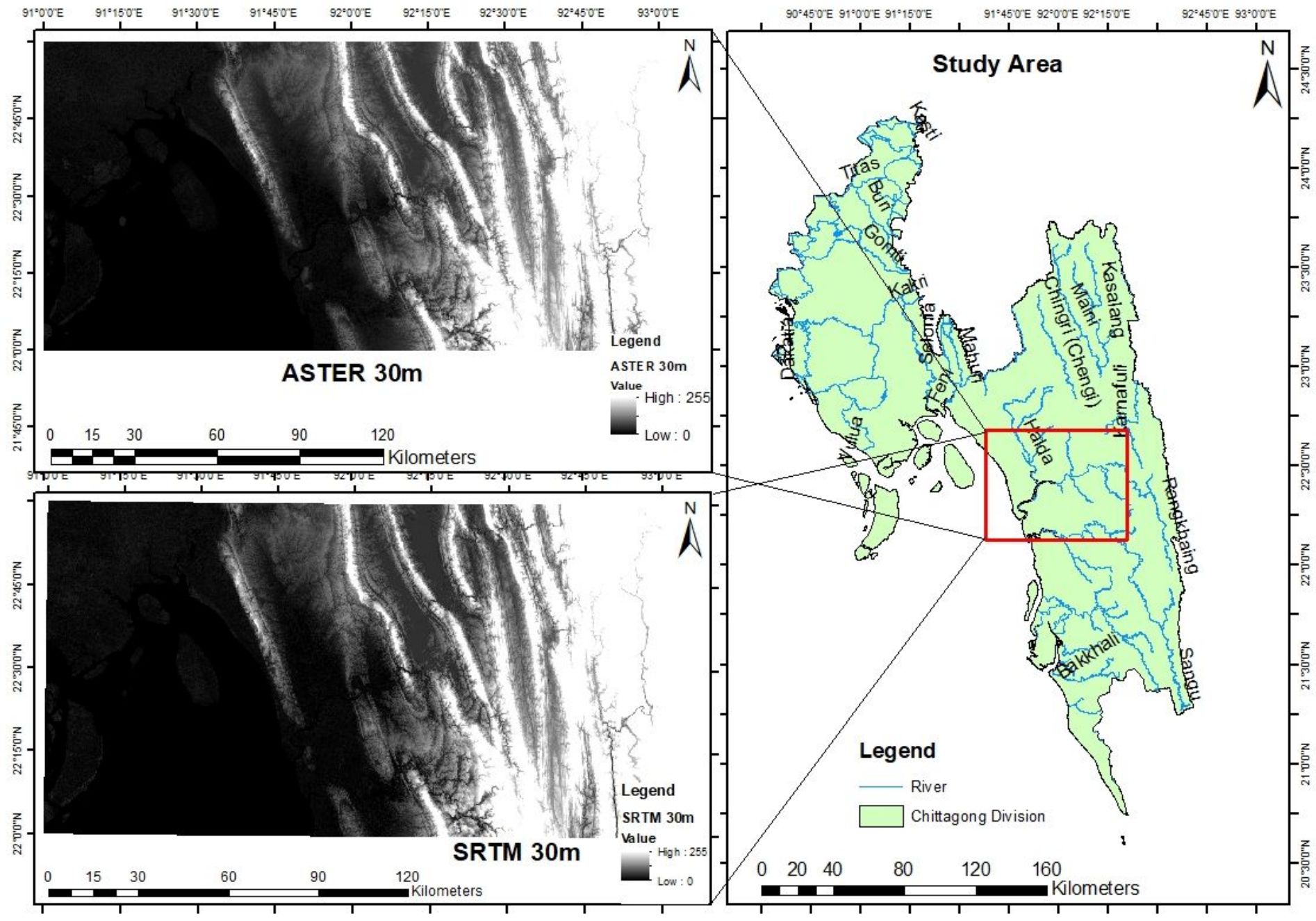

Figure 1

Location of Karnaphuli River in Chittagong, Bangladesh (Study Area) 


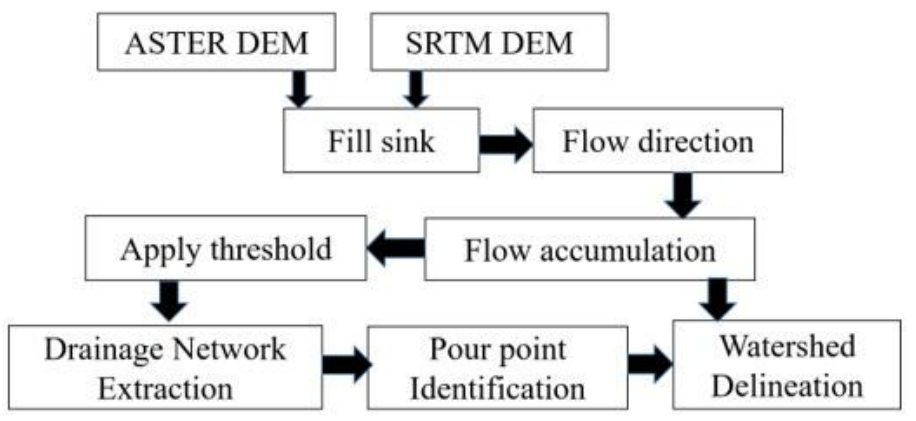

Figure 2

Methodology adopted for watershed delineation
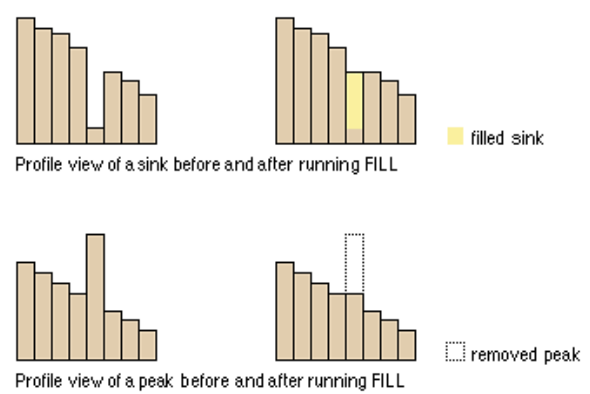

Figure 3

Before fill (up), After fill (down) 

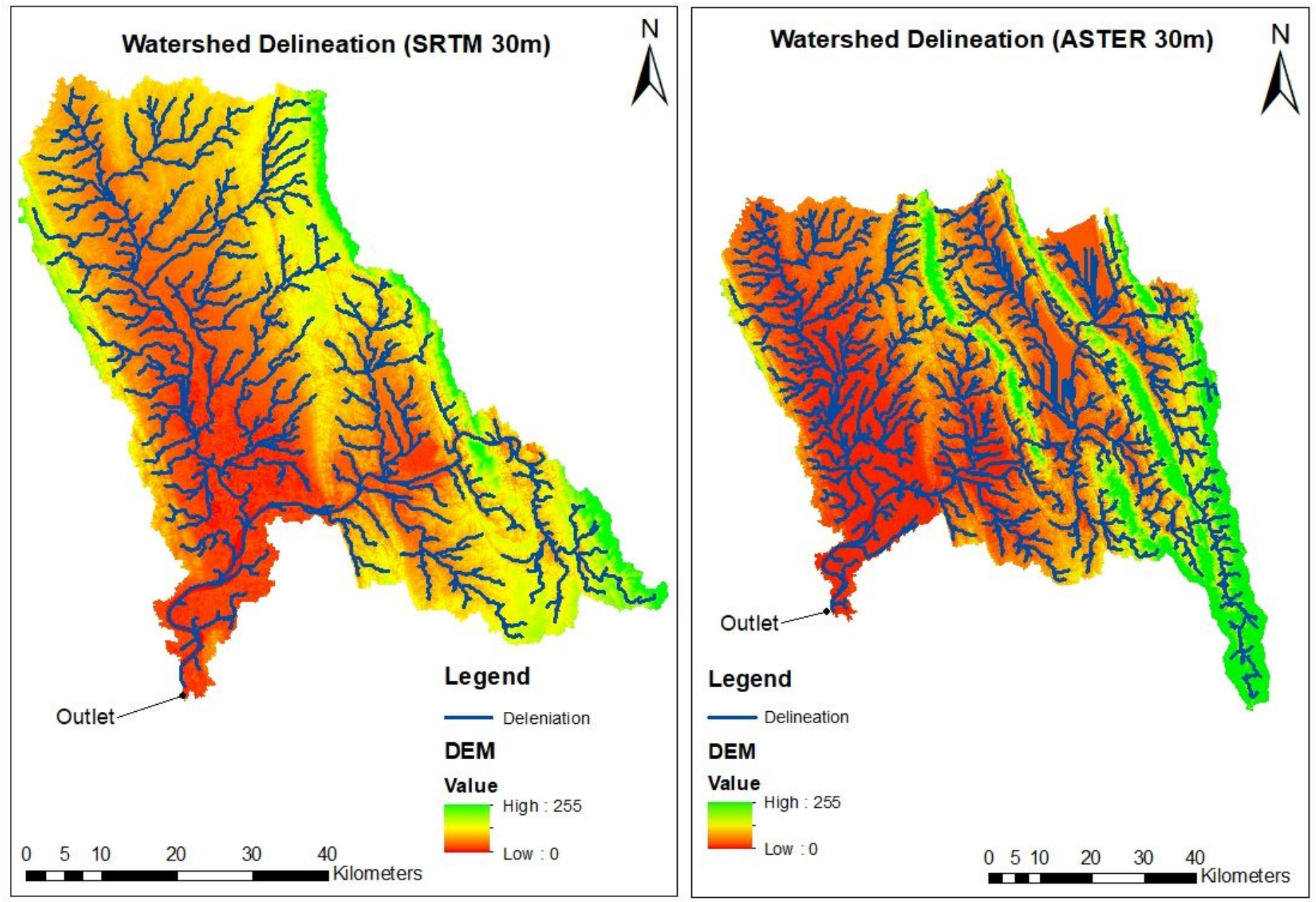

Figure 4

Watershed delineation using SRTM \& ASTER DEM 

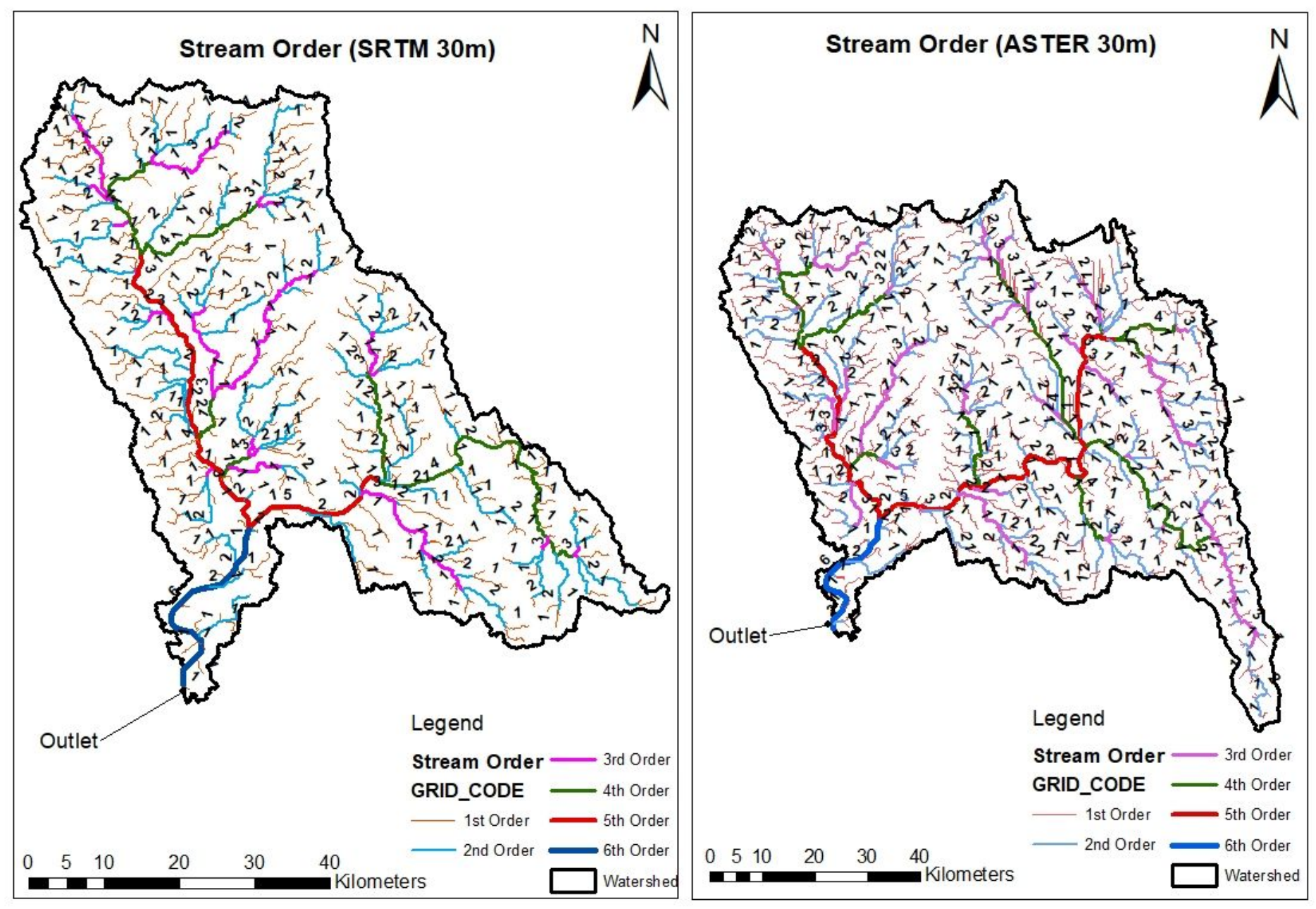

Figure 5

Stream Order 


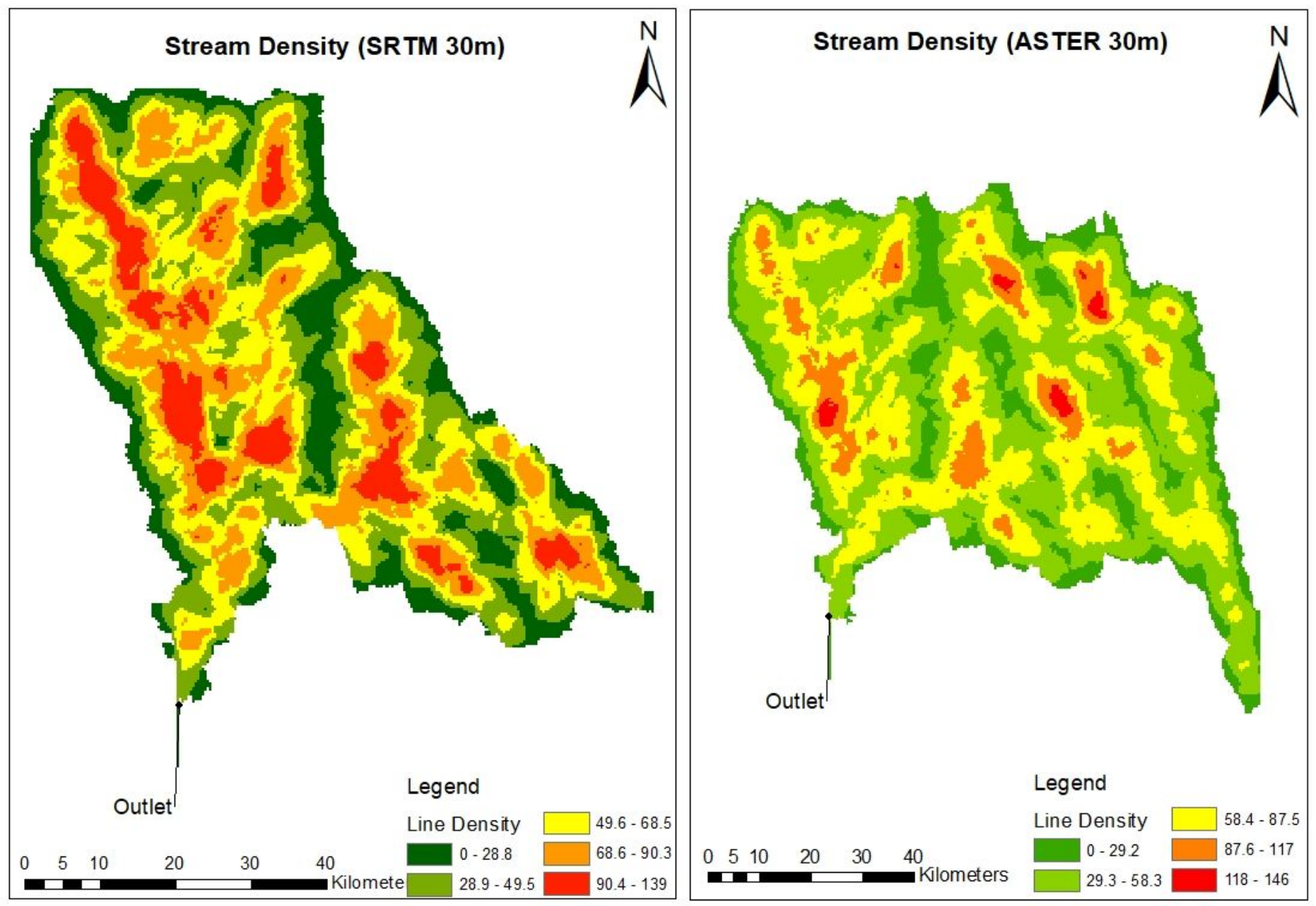

Figure 6

Stream Density of SRTM-30m DEM 

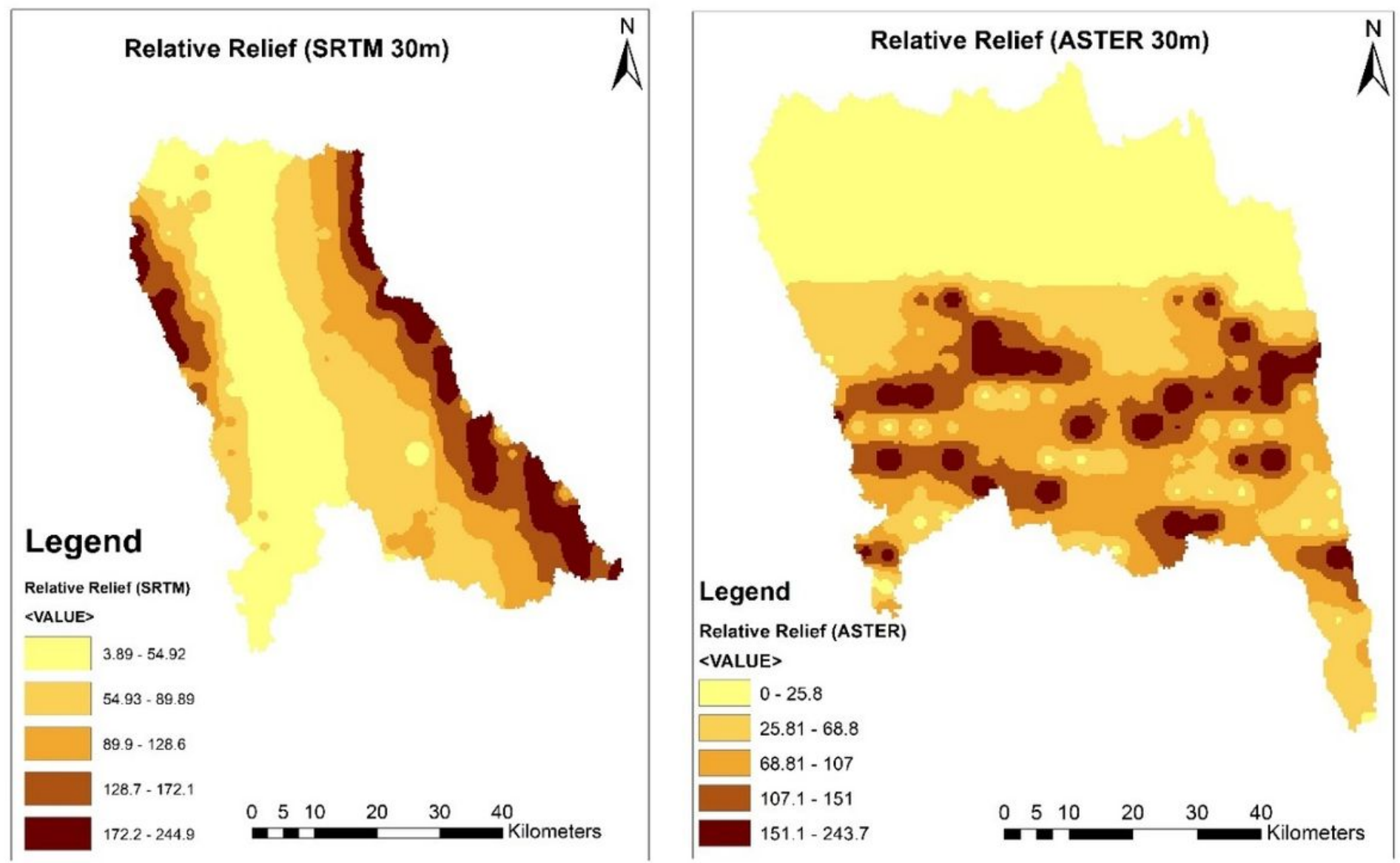

Figure 7

Relative Relief in then Study Area 


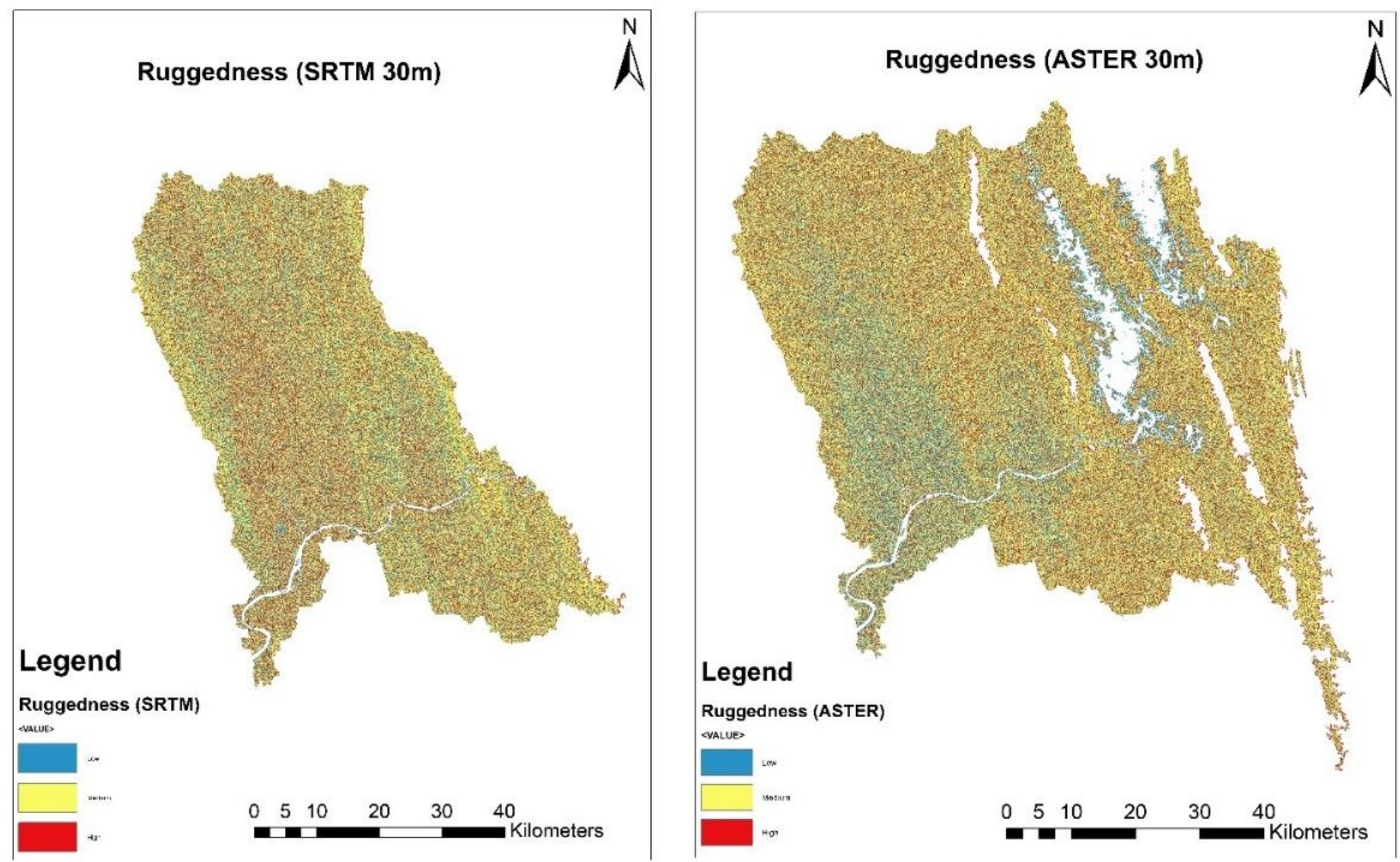

Figure 8

Ruggedness of the Study Area 